\title{
OPEN
}

\section{Author Correction: Matrix-bound nanovesicles prevent ischemia- induced retinal ganglion cell axon degeneration and death and preserve visual function}

\author{
Yolandi van der Merwe ${ }^{1,2,3}$, Anne E. Faust ${ }^{2,3}$, Ecem T. Sakalli ${ }^{3,4}$, Caroline C. Westrick ${ }^{1,3}$, \\ George Hussey ${ }^{3}$, Kevin C. Chan ${ }^{2}$, Ian P. Conner ${ }^{1,2,3}$, Valeria L. N. Fu², Stephen F. Badylak ${ }^{1,3,5}$ \& \\ Michael B. Steketee $\mathbb{i D}^{2,3,6}$ \\ Correction to: Scientific Reports https://doi.org/10.1038/s41598-019-39861-4, published online 05 March 2019
}

Kevin C. Chan was omitted from the author list in the original version of this Article. This has been corrected in the PDF and HTML versions of the Article.

The Author Contributions statement now reads:

Experimental design: Y.V.d.M., A.E.F., G.H., K.C.C., S.F.B., M.B.S. Conduct experiments: Y.V.d.M., A.E.F., E.T.S., C.C.W., G.H., I.P.C., V.L.N.F. Data analysis: Y.V.d.M., A.E.F., V.L.N.F. Manuscript writing: Y.V.d.M., A.E.F., S. F. B., M.B.S.. All authors read and approved the final manuscript.

\begin{abstract}
(c) (i) Open Access This article is licensed under a Creative Commons Attribution 4.0 International License, which permits use, sharing, adaptation, distribution and reproduction in any medium or format, as long as you give appropriate credit to the original author(s) and the source, provide a link to the Creative Commons license, and indicate if changes were made. The images or other third party material in this article are included in the article's Creative Commons license, unless indicated otherwise in a credit line to the material. If material is not included in the article's Creative Commons license and your intended use is not permitted by statutory regulation or exceeds the permitted use, you will need to obtain permission directly from the copyright holder. To view a copy of this license, visit http://creativecommons.org/licenses/by/4.0/.
\end{abstract}

(C) The Author(s) 2019

\footnotetext{
${ }^{1}$ Department of Bioengineering, University of Pittsburgh, Pittsburgh, PA, USA. ${ }^{2}$ Department of Ophthalmology, University of Pittsburgh, Pittsburgh, PA, USA. ${ }^{3} \mathrm{McG}$ owan Institute for Regenerative Medicine, University of Pittsburgh, Pittsburgh, PA, USA. ${ }^{4}$ Department of Molecular Biology, Bogazici University, Istanbul, Turkey. ${ }^{5}$ Department of Surgery, University of Pittsburgh, Pittsburgh, PA, USA. ${ }^{6}$ Center for Neuroscience, University of Pittsburgh, Pittsburgh, PA, USA. Stephen F. Badylak and Michael B. Steketee contributed equally. Correspondence and requests for materials should be addressed to M.B.S. (email: stek0323@gmail.com)
} 